\title{
A 2014 és 2018 között osztályos ellátást igénylő szemsérülések klasszifikációja a Markusovszky Egyetemi Oktatókórházban
}

\author{
Németh Orsolya dr. - Bátor György dr. \\ Markusovszky Egyetemi Oktatókórház, Szemészeti Osztály, Szombathely
}

\begin{abstract}
Bevezetés és célkitüzés: Dolgozatunk célja a 2014 és 2018 között osztályos ellátást igénylő szemsérülések klasszifikációja, epidemiológiai összefoglalása.

Módszer: Retrospektív módon vizsgáltuk a 2014. január 01. és 2018. december 31. között kórházunkban szemsérülés miatt osztályos ellátást igényló betegcsoportot. A vizsgálatba 97 beteg 98 szeme került bevonásra. A sérülések klasszifikációjához a Birmingham Eye Trauma Terminology (BETT) és a Shukla és mtsai által létrehozott kibővített klasszifikációt alkalmaztuk.

Eredmények: A vizsgált 97 páciensból 16 nő, 81 férfi volt. Az átlagos életkor 43,3 222,5 (min.: 3, max.: 92) év, 20 páciens 18 éven aluli volt. 46,4\%-nál a jobb szem, 52,5\%-nál a bal szem volt érintett, $1 \%$-nál kétoldali sérülés történt. A sérüléstól az ellátásig eltelt átlagos idő 1,3 nap volt. A sérülések kapcsán átlagosan kórházban töltött idő 5,2 nap, az átlagos obszervációs idő 9,7 hónap volt. A szemsérülések 95,8\%-a mechanikai sérülés volt, melyből 74,2\% szemgolyóra lokalizálódó sérülés, 20,4\% adnexumokat érintő, 5,4\% destruktív szemsérülés volt. A szemgolyót ért sérülések között 15 zárt, 60 a bulbus megnyílásával járó szemsérülés volt, és 21 esetben került idegen test a szemgolyóba. Az esetek 93\%-ában sikerült megőrizni vagy javítani a beteg legjobb korrigált látóélességét az ellátás során.

Köpetkeztetés: A kibővített klasszifikáció segítségével az osztályos ellátást igénylő összes szemsérülés csoportosíthatóvá vált. A szemsérülés mértékétôl függően az időben megfelelő ellátásban részesülő szemsérülések esetén javítható vagy megôrizhető a látóélesség.
\end{abstract}

Orv Hetil. 2019; 160(49): 1941-1947.

Kulcsszavak: szemsérülés, epidemiológia, klasszifikáció

The classification of ocular trauma cases between 2014 and 2018 at the in-patient ophthalmological department of the Markusovszky University Teaching Hospital

Introduction and aim: To analyse and classify the ocular trauma cases at the in-patient ophthalmological department of the Markusovszky University Teaching Hospital between 2014 and 2018.

Method: We analysed the eye injury cases between 01. 01. 2014 and 31. 12. 2018 in the in-patient clinic of our hospital. 98 eyes of 97 patients were included in this study. To classify the injuries, we used the Birmingham Eye Trauma Terminology (BETT) and the new expanded classification of Shukla et al.

Results: From the 97 patients, 16 were female and 81 male. The average age was $43.3 \pm 22.5$ (min.: 3 , max.: 92) years; 20 patients were younger than 18 years old. $46.4 \%$ of the cases were right eyes, $52.5 \%$ were left eyes, and $1 \%$ was bilateral. The average time from the injury until the treatment was 1.3 days. The average time spent in hospital because of the injury was 5.2 days. The average observation time was 9.7 months. $95.8 \%$ of the injuries were mechanical eye injuries. From this group, $74.2 \%$ localized only to the globe, $20.4 \%$ were adnexal injuries and $5.4 \%$ were destructive eye injuries. From the globe injuries, 15 were closed globe, 60 were open globe injuries, and in 21 cases there were intraocular foreign body present. In $93 \%$ of the cases it was possible to keep or improve the best corrected visual acuity during the treatment.

Conclusion: With the new classification, we could classify all of the eye injury cases easily. Depending on the type of the eye injury, with appropriate treatment we can keep or improve the visual function of the eye. 
Keywords: eye injuries, epidemiology, classification

Németh O, Bátor Gy. [The classification of ocular trauma cases between 2014 and 2018 at the in-patient ophthalmological department of the Markusovszky University Teaching Hospital]. Orv Hetil. 2019; 160(49): 1941-1947.

(Beérkezett: 2019. július 2.; elfogadva: 2019. július 26.)

\section{Rövidítések}

$\mathrm{BCVA}=($ best corrected visual acuity $)$ a legjobb korrigált látóélesség; BETT = Birmingham Eye Trauma Terminology; BETTS = Birmingham Eye Trauma Terminology System; $\mathrm{BNO}=$ betegségek nemzetközi osztályozása; ECCE = (extracapsular cataract extraction) üres lencsetokba helyezett múlencse; $\mathrm{ICCE}=($ intracapsular cataract extraction $)$ a szemlencse tokkal együtt történő eltávolítása; PCL $=$ (posterior chamber lens) hátsó csarnoki múlencse; RAPD = relatív afferens pupillaris defektus

Az egynapos általános tevékenységszüneteltetést okozó szemsérülések globális becsült incidenciája 950/100000 lakos évente, ami arra utal, hogy évente 55 millió ilyen típusú szemsérülés alakul ki világszerte. A hospitalizációt igénylő szemsérülések becsült globális incidenciája 13/100 000 lakos évente, ami 750000 esetet jelent. A perforált szemsérülések globális incidenciája 3,5/100 000 lakos évente [1].

A szemsérülések tekintetében számos kockázati faktorról számol be a szakirodalom. Ilyen az életkor, mely esetén két korcsoport (5-25 évesek, illetve a 70 éves kor felettiek) körében mutattak ki nagyobb incidenciát [2, 3]. A nemek tekintetében korcsoporttól függetlenül a férfiak dominanciája figyelhető meg, melynek aránya a 70 év feletti korcsoportra csökken, tekintettel a nók hosszabb átlagos élettartamára és a nemhez kötődő életmódra [1]. A szocioökonómiai környezet szempontjából az alacsonyabb életszínvonal jelent magasabb kockázati tényezőt [4]. Az életmód, a hétköznapi magatartás tekintetében viszont nagyobb a kockázat az iparosodott társadalomban, ahol több lehetőség nyílik a szemsérülések szempontjából magasabb kockázatú tevékenységek végzésére, mint például sportolás, motorkerékpár-vezetés, támadások [1].

Szemsérülések a mindennapi tevékenységek során alakulnak ki, mint a munkavégzés, házi munka során, tüzelőaprítás, kerti munkálatok, utazás, sportolás során vagy erőszakos cselekmények, háború ideje alatt.

A mechanikai szemsérülések standardizált klasszifikációjának létrehozása céljából 1997-ben hívták össze az „Ocular Trauma Classification Group”-ot, mely megalkotta a Birmingham Eye Trauma Terminology System (BETTS-) [5] klasszifikációt: ez széles körben elfogadott terminológiát vezetett be a szemsérülések leírására. Ezt követően Pieramici és mtsai létrehoztak egy részletes, a sérülést követő első szemészeti vizsgálaton alapuló osztályozási rendszert, mely figyelembe veszi a sérülés típusát, mechanizmusát, a sérülés fokát, melyet a látóélesség, a relatív afferens pupillaris defektus jelenléte vagy hiánya, illetve a sérülés zónája (anteroposterior kiterjedése) határoz meg [6].

A BETTS-klasszifikáció azonban kizárja a kémiai anyagok, elektromosság és hő hatására kialakuló sérüléseket, valamint nincs tekintettel a szem függelékeinek sérüléseire.

Ezen hiányosságok miatt Shukla és mtsai létrehoztak egy kibővített klasszifikációt, mely a korábbi csoportosítást is magában foglalja (1. táblázat). Kiterjed a szem függelékeinek sérüléseire; klasszifikálja a nem mechanikai sérüléseket is, valamint a sérülés oka és a kísérő sérülések alapján is csoportosít [7].

Az Ocular Trauma Classification Group 2500 szemsérülés vizsgálata során, az Egyesült Államok és a Magyar Szem Sérülések Regisztere segítségével azonosította a legjobb prediktorokat a sérülést követő 6 hónappal ta-

1. táblázat |A Shukla és mtsai által létrehozott klasszifikáció szerinti csoportosítás részlete (felsorolva a szemgolyót érintő és destruktív sérüléseket), mely a szemgolyósérülés patológiáját veszi figyelembe (az érintett bulbusok száma, százalékos aránya)

\begin{tabular}{|c|c|c|c|c|c|}
\hline \multicolumn{2}{|c|}{ Zárt szemgolyósérülések } & \multicolumn{2}{|c|}{ Nyitott szemgolyósérülések } & \multicolumn{2}{|c|}{ Destruktív szemgolyósérülések } \\
\hline Típus & Esetszám & Típus & Esetszám & Típus & Esetszám \\
\hline Contusio & $12(80 \%)$ & Ruptura & $9(16,4 \%)$ & Evisceratio & 0 \\
\hline Lamellaris laceratio & $1(6,6 \%)$ & Penetráció & $24(43,6 \%)$ & Enucleatio & 0 \\
\hline $\begin{array}{l}\text { Extraocularis idegen } \\
\text { test }\end{array}$ & $1(6,6 \%)$ & Perforáció & $1(1,8 \%)$ & $\begin{array}{c}\text { 1/3 teljes vastagságú } \\
\text { laceratio }\end{array}$ & 0 \\
\hline $\begin{array}{l}\text { Intramuralis idegen } \\
\text { test }\end{array}$ & $1(6,6 \%)$ & $\begin{array}{c}\text { Intraocularis idegen } \\
\text { test }\end{array}$ & $21(38,2 \%)$ & Phthisis & 5 \\
\hline & & & & Endophthalmitis & 0 \\
\hline Összesítés & 15 & & 55 & & 5 \\
\hline
\end{tabular}


pasztalható legjobb korrigált látóélesség tekintetében. A sérülések kapcsán a legerősebb prognosztikai faktoroknak bizonyuló tényezők segítségével (kezdeti látóélesség, szemgolyóruptura, endophthalmitis, perforált szemsérülés, retinaleválás, RAPD jelenléte) jósolhatóvá vált a sérülés végkimenetele [8]. Szakirodalmi adatok alapján a sérülés mechanizmusának tekintetében roszszabb prognosztikai faktor a bulbusruptura mechanizmusa, mint az intraocularis idegen test vagy a penetráló szemsérülés [9, 10]. Az 5 mm-nél kisebb sebméret esetén jobb végkimenetel várható $[11,12]$. Amennyiben a seb a hármas zónát érinti, tekintettel a hátsó szegmentum sérülésére, szintén rosszabb prognózis várható [9]. $\mathrm{Az}$ érkezéskor felvett legjobb korrigált látóélesség az egyik legfontosabb előrejelzője a várható látásfunkciónak. Jó kezdeti látóélesség esetén jobb funkcionális eredmény érhető el az ellátás során [10]. Számos korábbi tanulmány leírta, hogy szignifikáns korreláció van a lencse sérülése és az ellátást követő funkcionalitás között [9]. Intraocularis idegen test jelenléte esetén, bár jobb prognózis várható, mint szemgolyóruptura esetén, a funkcionalitás szempontjából mégis az idegen test helyzete a meghatározó. A retinaleválás és az üvegtesti vérzés szintén gyenge prognosztikai faktorok a látóélességet tekintve $[9,13]$.

\section{Betegek, módszer}

Retrospektív vizsgálatunk során 2014. január 1. és 2018. december 31. között a Markusovszky Egyetemi Oktatókórházban a szemészeti osztályos hospitalizációt igénylő szemsérüléseket vizsgáltuk. A keresési folyamat során a kórházban használatos egészségügyi rendszerben a sérüléseket jelölő BNO-kódok (S0000-S0590) alapján történt a páciensek azonosítása kizárólag a szemészeti, illetve gyermekosztályos ellátásra vonatkozóan.

Egyéb fekvőosztályok közremúködésével történő ellátás esetén (például politraumatizáció, kísérő koponyasérülések) a beteg vizsgálatunkba történő bevonásától eltekintettünk.

A páciensek beazonosítását követően az adatok gyưjtése során figyelembe vettük az érkezéskor létrehozott ambulánslapot, a kórházi bennfekvés során készült kórlapot, az utolsó kontrollról jegyzett dokumentációt. Vizsgáltuk a készített képalkotó eljárások leírását és képi anyagát, valamint az elvégzett beavatkozások leírását.

A dokumentáció áttekintése során gyújtöttük a demográfiai adatokat (életkor, nem, a sérülés mechanizmusa, a seb mérete, helyzete, idegen test jelenléte stb.), az érkezési és távozási legjobb korrigált látóélességet (BCVA = best corrected visual acuity) és az utolsó megjelenéskor rögzített legjobb korrigált látóélességet.

Elemeztük a sérülés részleteit (például traumás szürke hályog, üvegtesti vérzés, retinaleválás, irissérülés stb. jelenléte).

A BETTS, valamint a Shukla és mtsai által létrehozott klasszifikáció segítségével csoportosítottuk betegeinket.
A seb lokalizációját az Ocular Trauma Classification Group ajánlása alapján végeztük [7].

Vizsgálati anyagunkban limitációt jelentett a prognosztikai vizsgálatok során, hogy a kórházi dokumentációban a páciensek egy részénél hiányosan szerepeltek a pupillareakcióra vonatkozó leírások, illetve a pontos sebméret-meghatározás. Erre való tekintettel ennek elemzésétől eltekintettünk.

Vizsgáltuk a mütéti ellátás folyamatát, a mútéti ellátás idejét, a szükséges beavatkozások számát, típusát és azok okait.

\section{Eredmények}

A keresés során 97 páciens felelt meg a feltételeknek, így 97 páciens 98 szemét vizsgáltuk. A sérültek között 16 nő és 81 férfi volt. Átlagéletkoruk $43 \pm 22(\min .3$, max. 92) év, 20 páciens 18 éven aluli volt. Az érintettek 46,4\%ánál a jobb szem, 52,5\%-ánál a bal szem, 1\%-nál mindkét szem sérült. A sérüléstől az ellátásig eltelt idő átlagosan 1,3 nap volt. Egy páciens a sérülés után 2 hónappal jelentkezett. A betegek többsége (64 fö) a sérülés napján ellátásban részesült. A sérülés kapcsán átlagosan kórházban töltött idő $5,2 \pm 2,5$ nap volt. Az átlagos obszervációs idő 9,77 \pm 13 hónap volt.

A BETTS-klasszifikáció (1. ábra) alapján az osztályos ellátást igénylő betegeink 71,1\%-át tudtuk volna klasszifikálni; 28 páciens ezen klasszifikáción kívülre esik, ezért egy újabb kibővített klasszifikációt alkalmaztunk pácienseink csoportosítására.

A Shukla és mtsai által javasolt tágabb klasszifikáció alapján csoportosítva pácienseinket a beteganyag 100\%-a csoportosíthatóvá vált, melynek százalékos eloszlása a

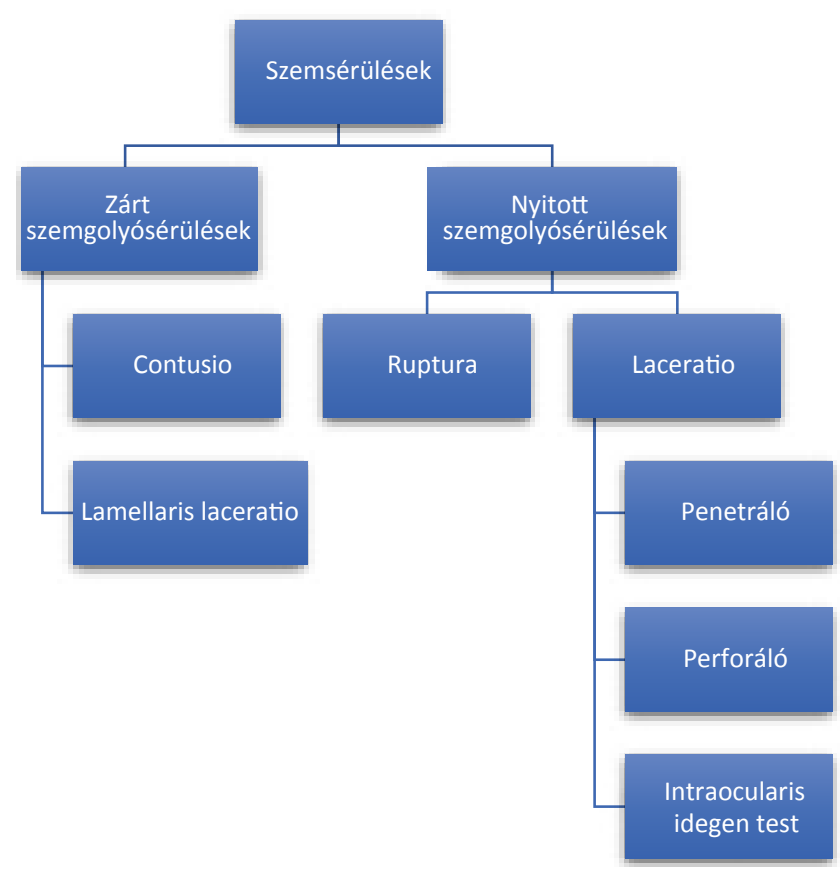

\begin{tabular}{l|l} 
1. ábra & A Kuhn és mtsai által létrehozott BETTS-nómenklatúra, klasszi-
\end{tabular} fikáció 


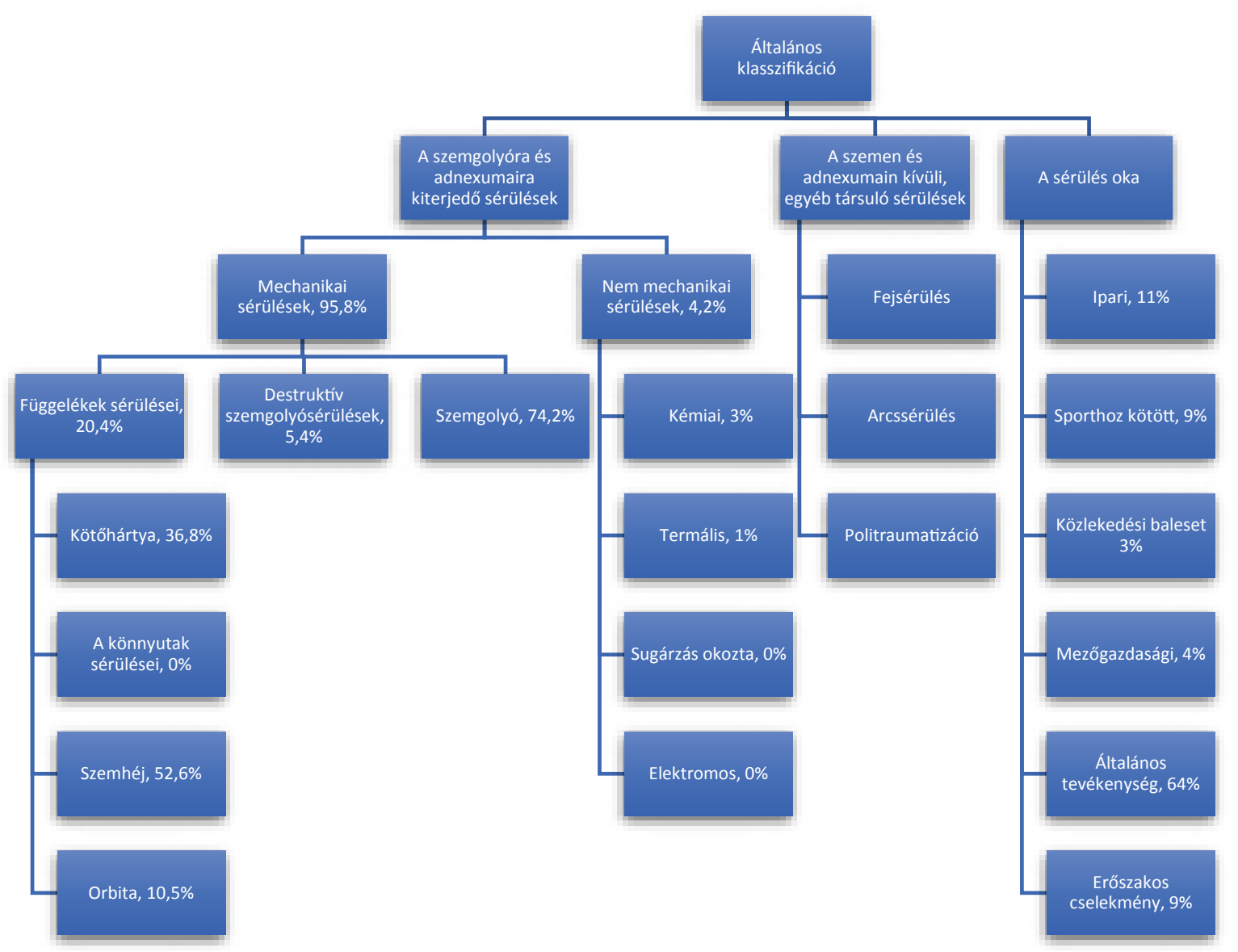

2. ábra

| A Shukla és mtsai által létrehozott klasszifikáció szerinti csoportosítás

2. ábrán látható. Vizsgálatunk során 2 csoportba soroltuk a sérülteket; a 'csak a szem és adnexumainak sérülése' csoportba csak azon betegek kerültek, akik sérüléséhez egyéb sérülés nem társult, mint például fejtrauma, koponyacsonttörés, politraumatizáció. Ezt követően a szemre és adnexumaira lokalizálódó sérüléseket további két csoportra, mechanikai $(95,8 \%, 94$ érintett szem és adnexum) és nem mechanikai (4,2\%, 4 érintett szem és adnexum) (kémiai, hőártalom, elektromos sérülés, sugárzás okozta) sérülésekre osztottuk. A mechanikai sérülések csoportján belül külön csoportot képez a szemgolyó sérülése (74,2\%, 70 szemgolyó), az adnexumok sérülése (20,4\%, 19 adnexum) és a destruktív szemgolyósérülések (5,4\%, 5 érintett szem), melyek a következők lehetnek: traumás evisceratio, enucleatio, $1 / 3$ teljes vastagságú laceratio, phthisis, endophthalmitis.

A sérülések oka tekintetében $11 \%$ történt ipari környezetben, munkahelyi baleset során. Shukla és mtsai klaszszifikációjának megjelölésében agrikulturális megnevezés szerepel. Esetünkben ide a mezőgazdasági munkát végző, illetve erdő- és vadgazdálkodási munka során sérült pácienseket soroltuk. Ezek szintén munkahelyi munkavégzés közben történt balesetek voltak. A teljes betegcsoportban dokumentációnk alapján csupán egy esetben viselt a sérült sérüléskor védőszemüveget. Ennek ellenére azonban a sérült áthatoló szemsérülést szenvedett el.
Az esetek 64\%-ában általános tevékenység végzése során történt a szemsérülés, mint például kertészkedés, kirándulás. Az idősebb korosztályban gyakrabban alakult ki sérülés elesést követően. Bántalmazás következtében kialakuló sérülések 9\%-ban fordultak elő, melyek közül egy esetben sörét eltávolítása történt a szemgolyóból.

Ezt követően alkalmaztuk a Shukla és mtsai által a szemgolyósérülések esetén javasolt klasszifikációt, mely csoportosításban a BETTS-klasszifikáció kiegészítésre került. A zárt és nyitott szemgolyósérülések mellett leírásra került a destruktív szemsérülések kategóriája. A zárt szemgolyósérüléseken belül az extraocularis és intramuralis idegen test okozta sérülések kategóriája jelent meg. Kórházunkba 15 , zárt szemgolyósérülést és 55 , nyitott szemgolyósérülést elszenvedett páciens érkezett. 5 esetben destruktív szemsérülés történt. A zárt sérülések esetén a contusio volt a leggyakoribb $(85,7 \%)$. A szemgolyó megnyílásával járó sérülések esetén a penetráló szemsérülések az esetek 43,6\%-át tették ki, ezt az intraocularis idegen testtel elszenvedett sérülés követi (35\%). Az intraocularis idegen testek közül (2l db) 17 fém-, 4 növényi eredetű idegen test volt.

A sérülés lokalizációja során az Ocular Trauma Classification Group [6] által létrehozott klasszifikációt használtuk. Zárt szemgolyósérülések esetén az első zónához a bulbaris kötőhártya, a sclera és a szaruhártya sérülései 
2. táblázat $\mid$ Az Ocular Trauma Classification Group által létrehozott, a sérülés helye szerinti klasszifikáció alakulása beteganyagunk esetén

\begin{tabular}{lcc}
\hline & $\begin{array}{c}\text { Zárt szemgolyósérülések } \\
(15)\end{array}$ & $\begin{array}{c}\text { Nyitott szemgolyósérülések } \\
(60)\end{array}$ \\
\hline I. zóna & 3 & 31 \\
II. zóna & 2 & 21 \\
III. zóna & 10 & 8 \\
\hline
\end{tabular}

3. táblázat |A jellemző ocularis károsodások előfordulása (esetszám)

\begin{tabular}{lccc}
\hline & $\begin{array}{c}\text { Zárt } \\
\text { szemgolyó- } \\
\text { sérülések } \\
\text { (esetszám) }\end{array}$ & $\begin{array}{c}\text { Nyitott } \\
\text { szemgolyó- } \\
\text { sérülések } \\
\text { (esetszám) }\end{array}$ & $\begin{array}{c}\text { Összesítve } \\
\text { (esetszám) }\end{array}$ \\
\hline Áthatoló szaruhártya-sérülés & 0 & 43 & 43 \\
Hyphaema & 6 & 28 & 34 \\
Irissérülés & 4 & 17 & 21 \\
Traumás szürke hályog & 1 & 23 & 24 \\
Subluxatio/luxatio/aphakia & 4 & 10 & 14 \\
Üvegtesti vérzés & 3 & 30 & 33 \\
Retinaleválás & 0 & 14 & 14 \\
Áthatoló sclerasérülés & 0 & 31 & 31 \\
Bulbusperforáció & 0 & 1 & 1 \\
Szekunder glaucoma & 3 & 9 & 12 \\
\hline
\end{tabular}

sorolandók; a második zónába az elülső szegmentum sérülései tartoznak a szemlencse hátsó tokjáig, beleértve a pars plicata sérüléseket is; a harmadik zóna károsodása esetén a hátsó szegmentum egy vagy több részét is érinti. Nyitott szemgolyósérülések esetén az első zónába azon teljes vastagságú sérülések tartoznak, melyek csak a szaruhártyát érintik; a második zónába azon teljes vastagságú sclerasérülések tartoznak, melyek nincsenek hátrébb a corneoscleralis átmenettôl (limbus), mint $5 \mathrm{~mm}$; a hármas zónába pedig a limbustól 5 mm-nél messzebb húzódó teljes vastagságú sclerasérülések tartoznak. Mindkét esetben a legsúlyosabb sérülés helye szerint csoportosítottunk. Adatainkat a 2. táblázat tartalmazza: a zárt szemgolyósérülések esetén 2 sérülésnél ezen klasszifiká- ció alapján bizonytalan besorolást tudtunk megadni. Az intramuralis elhelyezkedésú idegen test a lokalizáció alapján a III. zóna sérülései közé sorolandó, illetve a contusióval járó extraocularis, intraorbitalis idegen testtel történő sérülés szintén a III-as zónát érintette. A sérülések jellemzőit a 3. táblázatban foglaltuk össze. A 4. táblázatban szemléltetjük az osztályos felvételkor felvett legjobb korrigált látóélesség és az utolsó kontrollon felvett legjobb korrigált látóélesség viszonyát. A vizuális tengely 35 esetben volt érintett. Az összes eset 7\%-ában nem sikerült az érkezéskori legjobb korrigált látóélességen javítani, 12 esetben sikerült az érkezéskori látóélességet megtartani, az esetek 81\%-ában az utolsó kontrollon felvett legjobb korrigálható látóélesség javulást mutatott. A sérülést követôen 6 esetben az érintett szem fényérzés nélkülivé vált. Az obszervációs periódus alatt enucleatióra nem volt szükség. 3 esetben a pácienseket az ellátást követően más intézményben kontrollálták, 4 esetben a beteg látóélességét nem lehetett vizsgálni, 2 esetben a mútétet követóen a páciens nem jelentkezett kontrollvizsgálaton.

A sérülések ellátása minden esetben az érkezés napján történt. 21 esetben nem volt szükség mútéti ellátásra. Nyitott szemgolyósérülések esetén minden esetben az érkezést követő lehető legkorábbi primer sebzárás történt az endophthalmitis és az expulzív vérzés kivédése céljából. A sebzárás halasztása (24 óra; például éjszaka helyett munkaidőben történő ellátás) a szakirodalmi adatok szerint növeli az endophthalmitis kockázatát [1416]. Az esetek $70 \%$-ában primer átfogó rekonstrukció történt, vagyis a páciens nem szorult több beavatkozásra. A maximális lehetséges rekonstrukció céljából 11 esetben 2, 3 esetben 3, 3 esetben 4 alkalommal történt mútéti elláás. Primer átfogó rekonstrukciós ellátás során 25 esetben történt csak a sebszélek egyesítése, szükség esetén elülső szegmentumból történő idegentest-eltávolítással és elülsőcsarnok-rekonstrukcióval. Ezenfelül 9 esetben primeren elvégeztük a sérült szemlencse eltávolítását, melyből 2 esetben primeren múlencse-implantáció történt a hátsó csarnokba, egy esetben PCL-repozícióra volt szükség. 11 esetben történt pars plana vitrectomia a primer ellátás során. Az intraocularis idegen testet minden esetben eltvolítottuk. 2 esetben az üvegtesti teret

4. táblázat |Az érkezéskor és távozáskor felvett legjobb korrigált látóélesség alapján történő értékelés

\begin{tabular}{|c|c|c|c|c|c|c|}
\hline \multirow[b]{2}{*}{$\begin{array}{l}\text { Az érkezéskori legjobb korrigált } \\
\text { látóélesség (esetszám) }\end{array}$} & \multicolumn{6}{|c|}{ Az utolsó kontrollon felvett legjobb korrigált látóélesség (esetszám) } \\
\hline & $\begin{array}{l}\text { Fényérzés } \\
\text { nélkül }\end{array}$ & $\begin{array}{l}\text { Fényérzés/ } \\
\text { kézmozgáslátás }\end{array}$ & $0,005-0,095$ & $0,1-0,4$ & $\geq 0,5$ & $\begin{array}{c}\text { Nincs adat/nem } \\
\text { vehetö fel }\end{array}$ \\
\hline Fényérzés nélkül & 2 & & & & & \\
\hline Fényérzés/kézmozgáslátás & 4 & 6 & 1 & 4 & 9 & 2 \\
\hline $0,005-0,095$ & & 1 & 5 & & 11 & 1 \\
\hline $0,1-0,4$ & & & & 1 & 11 & \\
\hline$\geq 0,5$ & & 1 & 1 & & 33 & 2 \\
\hline Nincs adat/nem vehető fel & & & & & & 4 \\
\hline
\end{tabular}


gázzal töltöttük fel, 6 esetben szilikonolaj-implantáció történt.

Kétlépcsős ellátás során 3 esetben történt szekunder múlencse-implantáció, melyből két esetben hátsó csarnoki, egy esetben elülső csarnoki múlencse-implantációt végeztünk. Egy esetben az elmozdult PCL repozíciója történt. Ennél az esetnél primer sebzárás mellett szürkehályog-mütéttel kombinált vitrectomia zajlott. 5 esetben a második lépésben történt a traumás szürke hályog eltávolítása múlencse-implantációval (4 esetben phacoemulsificatiós technikával, egy esetben ECCE-mútéttel), melyből 2 esetben történt kiegészítő vitrectomia; egy esetben pedig perforáló keratoplasztikára volt szükség. 3 esetben a második lépésben tisztán vitrectomia történt: egy esetben retinaleválás miatt, két esetben pedig üvegtesti vérzés, szekunder glaucoma miatt.

Háromlépcsős ellátás során mindhárom esetben primeren szaruhártyaseb zárása történt, majd ezt követően két esetben másodlagosan szürkehályog-eltávolítás zajlott phacoemulsificatiós technikával és múlencse-beültetéssel a hátsó csarnokba. Egy esetben a második lépcsőben vitrectomia zajlott endophthalmitises jelek miatt, majd a harmadik lépcsőben történt szürkehályog-mútét. A harmadik lépcső esetén egy esetben lencsekéreg-maradvány eltávolítása történt, egy esetben pedig ismételt irisrekonstrukció és pars plana vitrectomia zajlott.

Négylépcsős ellátás esetén mindhárom esetben a sérülést követő korai (0-4 nap) vitrectomia ellenére is kialakuló retinaleválás miatt volt szükség további 2 , illetve 3 alkalommal vitrectomiára.

Zárt szemgolyósérülés miatt 4 alkalommal történt mütéti ellátás. Egy esetben intramuralis idegen test miatt történt pars plana vitrectomia az idegen test eltávolítása után ora serrata szakadás miatt. Egy esetben a tompa sérülés során a szemlencse az üvegtestbe süllyedt, ami miatt az első lépésben annak eltávolítása történt, a második lépésben pedig tervezetten iris-clip lencse implantációját végeztük. A harmadik esetünknél a szemlencse subluxatiója miatt ICCE-mütét, majd iris-clip lencse implantációja történt. Negyedik esetünknél múlencse-subluxatio, majd traumás maculalyuk kialakulása miatt 4 alkalommal történt beavatkozás.

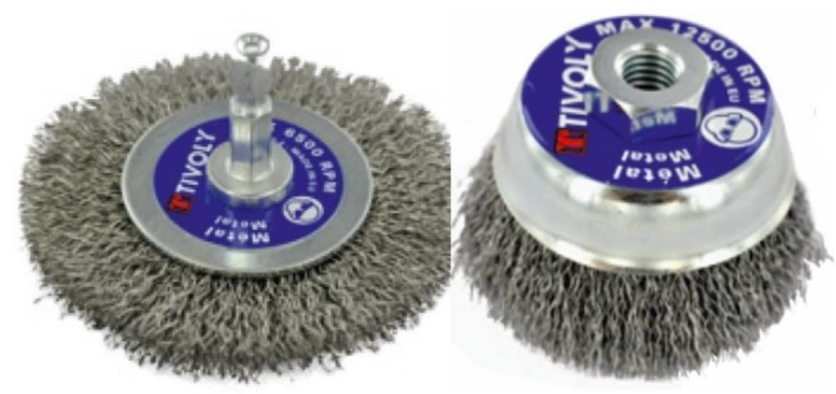

3. ábra

| Forgó drótkefe feje
A vizsgálatba bevont 5 év során 5 olyan beteg érkezett, akinél a destruktív szemsérülés miatt a szemgolyó megtartásán kívül a vizuális rehabilitáció nem volt lehetséges. Ezen esetekben a primer sebzárást követően szekunder beavatkozást nem tartottunk szükségesnek.

Betegeink ellátása alapján kiemelendő, hogy az utóbbi egy évben 3 alkalommal is előfordult forgó drótkefe (3. ábra) okozta sérülés, mint a betegcsoportunkban megjelenő új eszköz okozta sérülés (mint korábban a fükasza okozta sérülések). Ezen eszköz kopása, elhasználódása, a drótokat rögzítő fej fellazulása miatt a forgás során drótszálak repülhetnek ki nagy sebességgel használat közben, ami védőszemüveg hiányában szemsérülés esetén teljes látásvesztést is okozhat. Az így szembe került és általunk eltávolított fém drótszál hossza $22 \mathrm{~mm}$ volt.

\section{Következtetés}

Retrospektív vizsgálatunkban demográfiai szempontból tekintettük át és elemeztük az osztályos felvételt igénylő szemsérüléseket. A Shukla és mtsai által kibővített klaszszifikáció segítségével minden osztályos ellátást igénylő szemsérülés osztályozhatóvá vált, s ennek segítségével rálátásunk lett a sérülések okaira, körülményeire. Összefoglalásunk készítése során láthatóvá vált, hogy a sérülések egy része megelőzhető lett volna. A vizsgált 5 év folyamán a munkahelyi balesetek esetén a különböző eszközök, gépek használati szabályzatának ellenére védőszemüveg viselése csak egy esetben történt. A legtöbb páciensünk figyelmen kívül hagyta a leírt szabályzatban elóírtakat, vagy csak a helyi szokásoknak megfelelően használta a védőfelszerelést; például flexelésnél igen, de kalapácsolásnál nem. Fokozott figyelmet kell szentelnünk a hozzánk érkező munkahelyi feladatvégzés során sérült betegek tájékoztatására, a sérülésekkel járó súlyos látásvesztés lehetőségének felvetésével és nyomatékosításával. Kiemelten fontos azonban, hogy ne csak a munkahelyen, hanem az otthonukban végzett barkácsolás, kerti munkálatok, ház körüli teendők során is alkalmazzanak védőfelszerelést, tekintettel arra, hogy a sérülések számos formája ilyen körülmények között történt (fünyírás, tüzelőaprítás, kerítésjavítás, hajócsiszolás stb.).

Osztályunk beteganyagának elemzése során láthatóvá vált, hogy az operatőrök, amennyiben lehetséges, a mihamarabbi primer átfogó rekonstrukciót részesítik előnyben, amit az ellátás során a későbbiekben is folytatni tervezünk. A szakirodalmi adatok alapján a primeren elvégzett vitrectomia esetén jobb végső funkcionalitás nyerhető $[17,18]$.

Zárt szemsérülések esetén is szükség lehet szemmütétre, mint például a saját lencse subluxatiója, luxatiója üvegtesti vérzés, retinaleválás, maculalyuk miatt. Minden eset egyéni mérlegelést igényel a mütét és a mútéti időpont tervezése szempontjából, tekintettel a mútéti kockázatra.

Az egyes kórházi dokumentációk áttekintése rávilágított a sérülések részletes és pontos leírási hiányosságaira 
(például a pontos sebnagyság mérése), melyek ismeretével és rögzítésével tovább növelhetjük az ellátás színvonalát és pontosságát.

Anyagi támogatás: A kutatómunka és a kézirat elkészítése anyagi támogatásban nem részesült.

Szerzői munkamegosztás: N. O.: A vizsgálat lefolytatása, irodalomkutatás, a kézirat elkészítése, megszövegezése. B. Gy.: A kézirat szakmai átnézése. A cikk végleges változatát mindkét szerző elolvasta és jóváhagyta.

Érdekeltségek: A szerzőknek nincsenek érdekeltségeik.

\section{Irodalom}

[1] Négrel AD, Thylefors B. The global impact of eye injuries. Ophthalmic Epidemiol. 1998; 5: 143-169.

[2] Tielsch JM, Parver L, Shankar B. Time trends in the incidence of hospitalized ocular trauma. Arch Ophthalmol. 1989; 107: 519523.

[3] Klopfer J, Tielsch JM, Vitale S, et al. Ocular trauma in the United States. Eye injuries resulting in hospitalization, 1984 through 1987. Arch Ophthalmol. 1992; 110: 838-842.

[4] Strahlmann E, Elman M, Daub E, et al. Causes of paediatric eye injuries. A population-based study. Arch Ophthalmol. 1990; 108: 603-606.

[5] Kuhn F, Morris R, Witherspoon CD. Birmingham Eye Trauma Terminology (BETT): terminology and classification of mechanical eye injuries. Ophthalmol Clin North Am. 2002; 15: 139143.

[6] Pieramici DJ, Sternberg P Jr, Aaberg TM, et al., the Ocular Trauma Classification Group. A system for classifying mechanical injuries of the eye (globe). Am J Ophthalmol. 1997; 123: 820831.

[7] Shukla B, Agrawal R, Shukla D, et al. Systematic analysis of ocular trauma by a new proposed ocular trauma classification. Indian J Ophthalmol. 2017; 65: 719-722.

[8] Kuhn F, Maisiak R, Mann L, et al. The Ocular Trauma Score (OTS). Ophthalmol Clin North Am. 2002; 15: 163-165.

[9] Han SB, Yu HG. Visual outcome after open globe injury and its predictive factors in Korea. J Trauma 2010; 69: E66-E72.

[10] Pieramici DJ, MacCumber MW, Humayun MU, et al. Openglobe injury. Update on types of injuries and visual results. Ophthalmology 1996; 103: 1798-1803.

[11] Rofail M, Lee GA, O'Rourke P. Prognostic indicators for open globe injury. Clin Exp Ophthalmol. 2006; 34: 783-786.

[12] Entezari M, Rabei HM, Badalabadi MM, et al. Visual outcome and ocular survival in open-globe injuries. Injury 2006; 37: 633637.

[13] Brinton GS, Aaberg TM, Reeser FH, et al. Surgical results in ocular trauma involving the posterior segment. Am J Ophthalmol. 1982; 93: 271-278.

[14] Kuhn F. The timing of reconstruction in severe mechanical trauma. Ophthalmic Res. 2014; 51: 67-72.

[15] Bhagat N, Nagori S, Zarbin M. Post-traumatic infectious endophthalmitis. Surv Ophthalmol. 2011; 56: 214-251.

[16] Faghihi H, Hajizadeh F, Esfahani MR, et al. Posttraumatic endophthalmitis: report No 2. Retina 2012; 32: 146-151.

[17] Erakgun T, Egrilmez S. Prognostic factors in vitrectomy for posterior segment intraocular foreign bodies. J Trauma 2008; 64: 1034-1037.

[18] Szijártó Z, Gaál V, Kovács B, et al. Prognosis of penetrating eye injuries with posterior segment intraocular foreign body. Graefes Arch Clin Exp Ophthalmol. 2008; 246: 161-165.

(Németh Orsolya dr., Szombathely, Markusovszky u. 5., 9700 e-mail: nemeth.orsolya22@gmail.com)

\section{A rendezvények és kongresszusok híranyagának leadása}

a lap megjelenése előtt legalább 40 nappal lehetséges, a 6 hetes nyomdai átfutás miatt. Kérjük megrendelőink szíves megértését.

A híranyagokat a következő címre kérjük:

Orvosi Hetilap titkársága: edit.budai@akademiai.hu

Akadémiai Kiadó Zrt.

A cikk a Creative Commons Attribution 4.0 International License (https://creativecommons.org/licenses/by/4.0/) feltételei szerint publikált Open Access közlemény, melynek szellemében a cikk bármilyen médiumban szabadon felhasználható, megosztható és újraközölhető, feltéve, hogy az eredeti szerző és a közlés helye, illetve a CC License linkje és az esetlegesen végrehajtott módosítások feltüntetésre kerülnek. (SID_1) 